\title{
Long-term analysis of price, productivity, and profitability trends in New Zealand agriculture
}

\author{
J. COCKS ${ }^{1}$ and C. BROWN ${ }^{2}$ \\ ${ }^{1}$ Abacus Biotech, P.O. Box 5585, Dunedin \\ ${ }^{2}$ Thomas Electronics, P.O. Box 1590, Dunedin \\ jcocks@abacusbio.co.nz
}

\begin{abstract}
Much has been written and spoken over the years about continually declining inflation adjusted commodity prices, the volatility of the New Zealand dollar, and the difficulties of competing against subsidized agricultural sectors. While NZ agriculture has enjoyed good levels of profitability in recent years these underlying forces still remain and will continue to impact farm profitability. Rising land prices and improved productivity of our competitors are likely to erode NZ agriculture's tr aditional position as a low cost producer in the future. The commonly cited responses to the forces outlined above are 1) adding value to commodities, and 2) increasing productivity. An earlier analysis showed that the NZ sheep and beef sector, in particular, was experiencing decreasing prices in real terms and farm productivity had remained largely unchanged for fifty years. In contrast to the data reviewed earlier, this paper shows that over the last fifteen years the NZ agricultural industry has been exhibiting just those responses required to combat the forces above. New Zealand lamb prices have increased in real terms since the late-1980s and in comparison with international prices. Beef and dairy prices have also fallen substantially less than the comparative international price, however wool and wheat prices have fallen more than the international price. In addition, there have been significant increases in farm productivity, most notably lambing percentage, lamb carcass weights, and milksolids production/ cow. The result has been a $57 \%$ increase in dairy Earnings Before Inter est and Tax (EBIT) over the past 5 years, compared with the previous half decade (measured in real terms). Sheep farming has experienced a $79 \%$ increase in EBIT over the same period. The challenge and subject of significant debate which is outside the scope of this paper is how NZ agriculture is to remain at the forefront of global pastoral agriculture as a low cost, innovative, and profitable sector.
\end{abstract}

Keywords: agricultural productivity, farm profitability, product prices, New Zealand agriculture.

\section{Introduction}

This paper is in four sections. The first looks at macroeconomic trends as these are important in understanding price trends and how the exchange rate and inflation have impacted agricultural prices over time. In the second section, $\mathrm{NZ}$ commodity prices are compared with international prices. The third section summarises changes in production and productivity, with the final section describing the impact of the above forces on dairy and sheep and beef farm profita bility.

\section{Methodology}

This paper updates a database originally developed by Brown (1996) for prices and production and adds profitability data. Data is sourced from Dexcel, the International Monetary Fund (IMF), Livestock Improvement Corporation (LIC), New Zealand Ministry of Agriculture and Forestry (MAF), Meat and Wool New Zealand's Economic Service (MWNZES), and the Reserve Bank of New Zealand (RBNZ).

Agricultural commodity prices are expressed in real terms from 1975; international commodities are adjusted for inflation using the US consumer price index (CPI) (1975 base year), and NZ commodities using the NZ CPI (1975 base year). To compare the relative changes in NZ prices irrespective of changes in the value of the NZ dollar, NZ real prices are adjusted for the change in the exchange rate for data post-1985. Commodity Trade Weighted Indexes (TWI) developed by MWNZES are used for beef, lamb and wool, the Australian dollar is used for wheat, the RBNZ TWI is used for dairy, and the Deutschmark and Euro are used for venison. Post-1985 data is used due to the unavailability of individual commodity TWIs prior to 1985 .

A 200 ha equivalent Southland property is used for comparisons of relative profitability for sheep versus dairy farms. A Southland base has been used because its soil type and climate has allowed swings in and out of dairying without major investment in irrigation systems. Five-year averages for each half decade are used, to even out short term fluctuations, and no account has been taken of relative capital employed, nor any analysis of return on investment capital attempted. Sheep profitability data is sourced from MWNZ economic service survey of class seven (Southland Intensive Finishing) sheep and beef farms. Data is adjusted for inflation. No clear dairy profitability data could be sourced for the period prior to 1986. Post-1986, the NZ Dairy Board and latterly Dexcel have collected economic surveys of dairy farmers. Therefore it has not been possible to make relative profitability comparisons for the period prior to 1986 . Earnings Before Inter est and Tax - Gross Farm Income 
Figure 1 Nominal TWI, relative CPI, and real exchange rate.

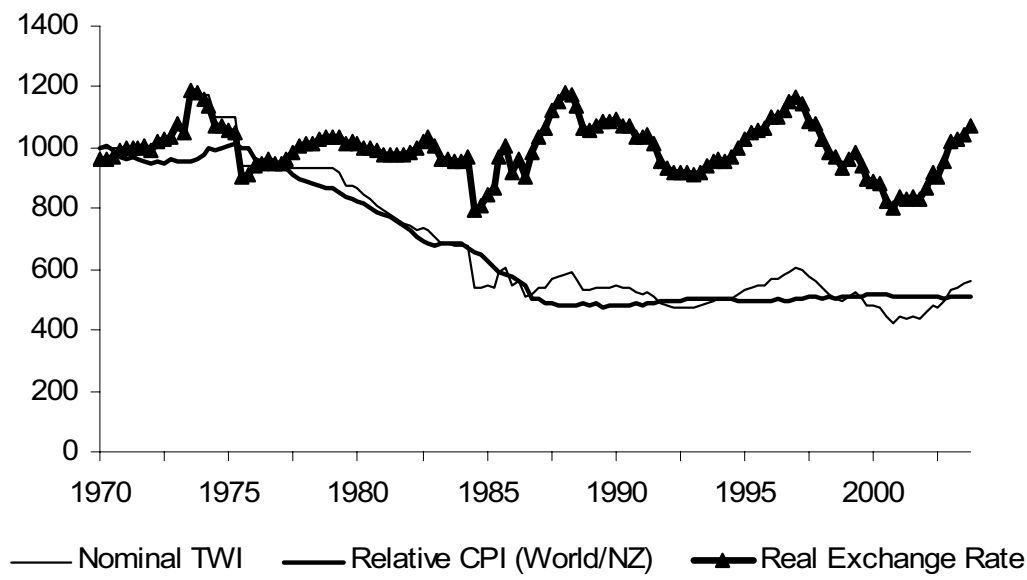

Source: Reserve Bank of New Zealand.

Figure 2 Meat and Wool NZ TWI for lamb, beef, wool and the Reserve Bank TWI from 1985-2004.

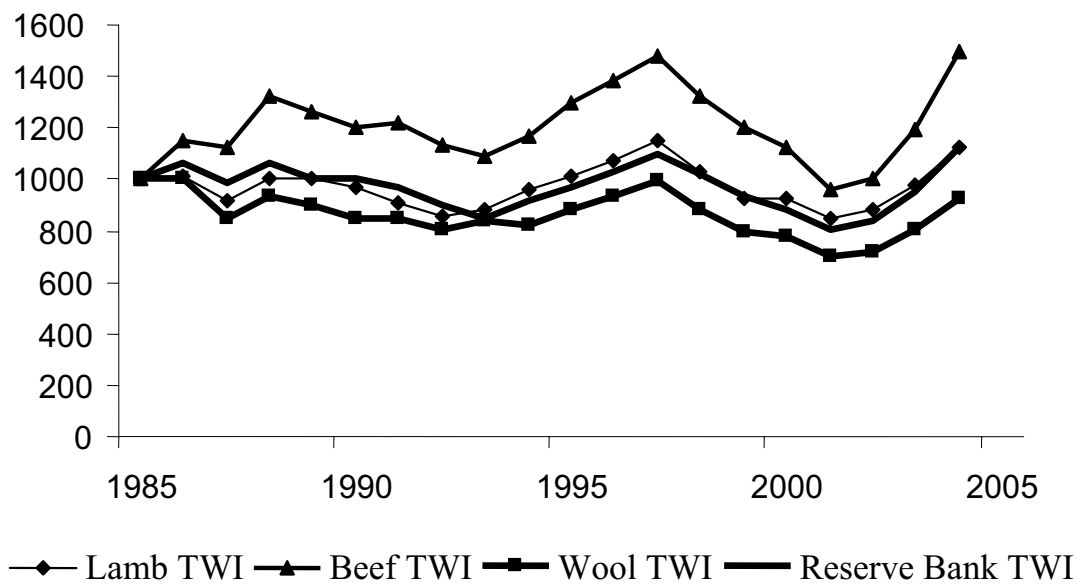

Source: Data adapted from MWNZES.

(GFI) less Farm Working Expenses (FWE) and Depreciation is used as the profitability measure. Economic Farm Surplus is not used as the profitability measure because wages of management can not be included due to differences in calculation methods over time and between industries.

\section{Macroeconomic trends}

\section{The New Zealand dollar}

Over the long-term the key drivers of the NZ exchange rate are our inflation rate and productivity growth relative to that of our trading partners (Brash 1992; Davison 1995). ${ }^{1}$ Examining Figure 1 shows that our real (inflation adjusted) exchange rate has been relatively unchanged, despite short-term volatility, since 1970 as the nominal TWI followed NZ's relative $\mathrm{CPI}^{2}$.

As is widely appreciated, there have been fluctuations within this long-term trend where the real exchange rate has risen or fallen $20 \%$ either side of the trend line. These fluctuations in almost all cases

\footnotetext{
1 Indeed, Davison (2004) reported that $94 \%$ of the variation in exchange rate for the period July 1970 to March 1996 was attributed to NZ's inflation rate relative to our trading partners.

2 The large decline in our nominal exchange rate occurred when our annual inflation exceeded that of our trading partners during the period 1975 to 1986 (Brown 1996). Since the dollar was floated in 1985 and monetary policy has curbed inflation, the nominal TWI has been relatively constant.
} 
Table 1 Long-term trends for commodity TWls and currencies between the time periods 1985-1989 and 2000$2004^{56}$.

\begin{tabular}{|c|c|c|c|}
\hline & $\begin{array}{c}1985-1989 \\
\text { average }\end{array}$ & $\begin{array}{c}2000-2004 \\
\text { average }\end{array}$ & Difference \\
\hline Lamb TWI & 100 & 96 & $-4 \%$ \\
\hline Beef TWI & 100 & 99 & $-1 \%$ \\
\hline Wool TWI & 100 & 84 & $-16 \%$ \\
\hline Reserve Bank TWI (dairy) & 100 & 90 & $-10 \%$ \\
\hline German Deutschmark (venison) & 100 & 83 & $-17 \%$ \\
\hline Australian dollar (wheat) & 100 & 108 & $8 \%$ \\
\hline \multicolumn{4}{|c|}{$\begin{array}{l}5 \text { The TWI has been averaged over five years ( } 1985-1989 \text { as the start period and } 2000-2004 \text { as the end period) to avoid biasing the } \\
\text { difference between the start and end points because short-term fluctuations can give a false impression on relative changes in } \\
\text { exchange rates. } \\
{ }^{6} \text { The Reserve Bank TWI, the Deutschmark, and the Australian dollar are used as a general indicators for the impact of the exchange rate } \\
\text { on dairy, venison, and wheat prices respectively as individual TWl's could not be sourced for these commodities. Post-floating of the } \\
\text { Euro the Deutschmark uses the weighting given to the Deutschmark as it was brought into the Euro. }\end{array}$} \\
\hline \multicolumn{4}{|c|}{ Source: Data adapted from MWNZES and RBNZ. } \\
\hline
\end{tabular}

occurred when the nominal exchange rate was increasing or decreasing relative to inflation. Depending on which way the exchange rate was moving, this equated to increasing or decreasing returns to exporters (or in our case farmers). For example, the periods 1988-1991 and 1997-2001 resulted in increasing returns to exporters as the exchange rate was moving downward relative to inflation, while the periods 1993-1996 and 20012004 resulted in the opposite (Figure 1). What these short-term fluctuations tend to hide is the fact that over the long-term the real exchange rate has been relatively constant, which is possibly contrary to popular belief.

\section{The exchange rate and individual commodities}

The extent to which individual commodities are impacted by exchange rate movements depends on the value of the NZ dollar in the export markets that each individual commodity is sold to. This value can be expressed in a TWI based upon the final end markets for each relative commodity ${ }^{3}$. For example the beef TWI which has a higher weighting toward the US dollar more closely expresses the volatility of the Kiwi dollar against the greenback in comparison to commodities sold into a wider basket of countries, such as lamb and wool, which track the path of the Reserve Bank TWI more closely (Figure 2).

Three important points can be extracted from Table 1 and Figure 2 . The first is already widely understood, and relates to farmers selling and budgeting decisions. Because of the weighting of the US dollar in the beef TWI, farmers selling beef should place greater attention on the value of the greenback, while farmers selling lamb or wool should place greater attention on the value of the TWI. Notwithstanding that many trading deals are negotiated in US dollars, it could be argued that many sheep farmers place disproportionate focus on this currency.

Secondly, the position of the TWI for each commodity in comparison with the long-term trend line indicates the impact of the exchange rate on the commodity price at that particular point in time. For example the respective commodity TWIs for lamb, wool, and beef at the end of 2003 had just moved above the long-term trend line. This means the exchange rate at the end of 2003 was just starting to have a negative impact on price compared to the long-term average. Given the cyclical nature of TWI movements, this would be likely to strengthen and continue for 3 to 4 years.

The third point is taken from examining the long-term impact of exchange rate movements on commodity prices since 1985 . The NZ dollar has depreciated against all commodity TWIs and relevant currencies with the exception of the Australian dollar (Table 1). This effectively means that movements in the NZ dollar from the period 1985-1989 to the period 2000-2004 have had a positive impact on farmgate prices for all commodities except wheat.

\section{Commodity price trends}

Worldwide agricultural commodity prices have traditionally fallen in inflation adjusted terms with Brown (1996) showing that the majority of NZ's agricultural commodities had been no exception. However, when comparing the latter half of the 1980 s with the five years to 2004, NZ lamb has actually reversed this trend, and beef and dairy have markedly slowed the downward slide. Table 2 summarises percentage chang es in the real price in NZ dollars, the real price after the impact of movements in the NZ dollar have been removed, and the international real price for six key agricultural commodities between the period 1985-1989 and 2000-

${ }^{3}$ For example a $30 \%$ weighting is given to Japanese Yen if $30 \%$ of the commodity is sold in Japanese Yen. 
Table 2 Percentage change in real prices for NZ commodities between the time periods 1985-1989 and 2000$2004^{7}$.

\begin{tabular}{|c|c|c|c|}
\hline Commodity & $\begin{array}{l}\text { Change in real } \\
\text { NZ price }\end{array}$ & $\begin{array}{l}\text { Change in real } \mathrm{NZ} \text { price } \\
\text { adjusted for exchange } \\
\text { rate movements }\end{array}$ & $\begin{array}{c}\text { Change in real } \\
\text { international price }\end{array}$ \\
\hline $\begin{array}{l}\text { Lamb } \\
\text { Beef } \\
\text { Wool } \\
\text { Dairy } \\
\text { Venison } \\
\text { Wheat }\end{array}$ & $\begin{array}{c}97 \% \\
0 \% \\
-43 \% \\
16 \% \\
-29 \% \\
-22 \% \\
\end{array}$ & $\begin{array}{c}89 \% \\
-3 \% \\
-52 \% \\
3 \% \\
-15 \% \\
-51 \% \\
\end{array}$ & $\begin{array}{c}-7 \% \\
-42 \% \\
-37 \% \\
-39 \% \text { (butter) } \\
-24 \%\end{array}$ \\
\hline \multicolumn{4}{|c|}{$\begin{array}{l}{ }^{7} \text { While not a focus of this paper, it is noted that venison and wheat prices have exhibited downward trends (Table 2). The NZ wheat pric } \\
\text { decreased } 51 \% \text { while the international price fell } 24 \% \text { - potentially the result of transportation and scale efficiencies international } \\
\text { relative to NZ. } \\
\text { Source: Data adapted from IMF, LIC, MAF Policy and MWNZES. }\end{array}$} \\
\hline
\end{tabular}

2004. By removing the impact of changes in the exchange rate, NZ real prices can be compared directly with international prices irrespective of exchange rate movements.

\section{Sheep and beef prices}

From the mid-1970s to the late-1980s the NZ lamb price followed the general downward trend experienced for the international lamb price in real terms (Figure 3). This trend changed from the late-1980s and due to a number of factors including advances in production (carcass weight, time of supply), processing (processing productivity, meat quality and consistency, packaging and storage), and marketing (value added processing, retailer alignment) sufficient value was added to lamb that it did not experience the downward trends shown for commodities globally. In actual fact NZ farmers received $97 \%$ more per $\mathrm{kg}$ of lamb meat sold (in real terms) over the 2000-2004 period than they did during the 1985-1989 period (Table 2). After advantages gained from a weakened exchange rate were removed, the NZ price was still $89 \%$ higher, while the international benchmark lamb price (frozen, UK) was 7\% lower. As a result of processing efficiency gains, farmers are now paid $70 \%$ of a higher free-on-board price compared to $50 \%$ twenty years ago (West 2005).

The NZ crossbred wool price experienced a general decline in real terms from 1975 (Figure 4), however from the early-1990s the relative rate of decline flattened out. Examination of wool prices highlights two areas of discussion pertaining to the performance of the industry; firstly, the w oolTWI has been decreasing $(16 \%$ reduction from the 1985-1989 period to the 2000-2004 period) which indicates a positive exchange rate impact on the $\mathrm{NZ}$ wool price, yet the price paid to NZ farmers has decreased $43 \%$ in real terms over the same period; and

Figure 3 Inflation adjusted NZ $(\$ / \mathrm{kg})$ and international lamb price (c/lb), and NZ lamb price adjusted for relative TWI movement (1990 base year).

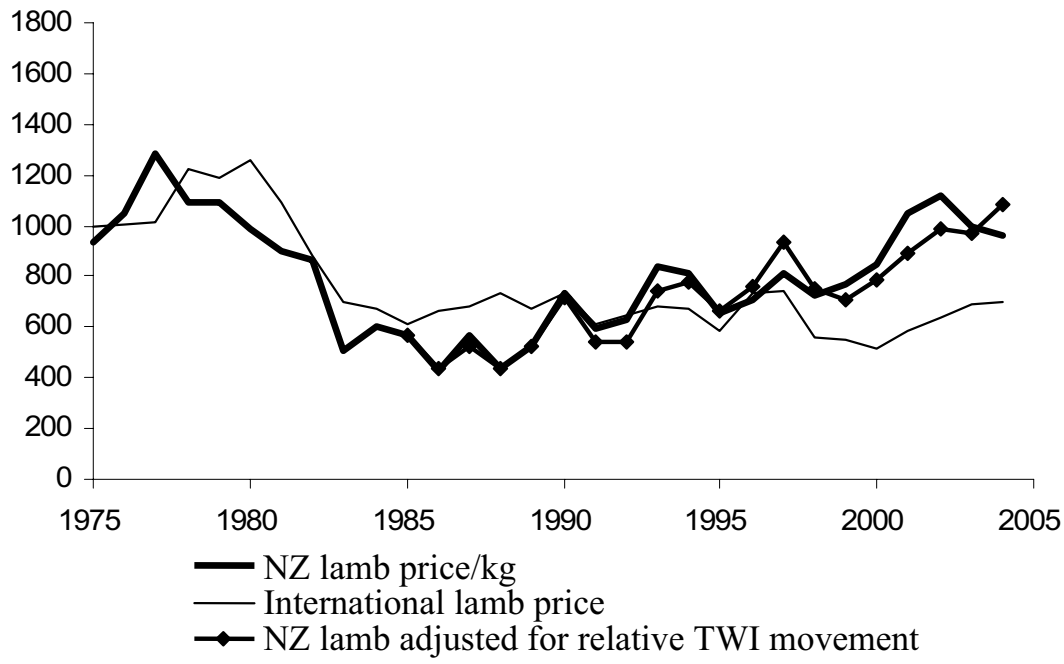


Figure 4 Inflation adjusted NZ (c/kg) and international crossbred wool price, and NZ wool price adjusted for relative TWI movement (1990 base year).

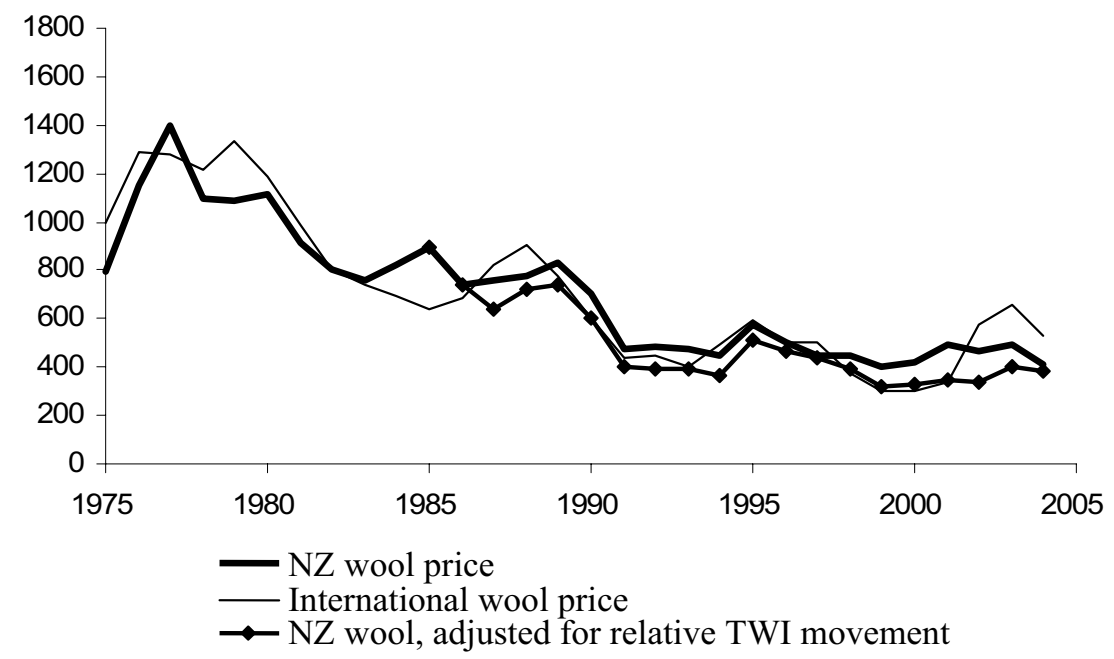

Source: Data adapted from IMF, MAF Policy and MWNZES.

secondly, the international wool price has decreased $37 \%$ over the above period while the NZ price after adjusting for exchange rate has decreased $51 \%$. This analysis confirms what many sheep and beef farmers implicitly know, in that wool is a declining part of their business.

The beef price received by NZ farmers hasn't followed the international price over short time frames (five-year periods) between 1975 and 2004 (Figure 5). An example of this divergence is since the period 1985-1989 to the period 2000-2004, the international beef price decreased $42 \%$ while the NZ price has only fallen $3 \%$ after adjusting for exchange rate movements (Table 2). Foot and Mouth
Disease and BSE in Europe are possible explanations for this divergence in the early-2000's.

\section{Dairy prices}

The NZ milk price has shown similar resilience in the face of falling commodity prices (Figure 6). At the same time as the international butter price fell $37 \%$ the NZ milksolids (MS) price to farmers rose 3\% after exchange rate movements were removed. This is obviously a reflection of the skill and ability of the NZ dairy industry at the production, processing, and marketing levels of the chain over the past twenty years. The obvious

Figure 5 Inflation adjusted NZ and international beef price, and NZ beef price adjusted for relative TWI movement (1990 base year).

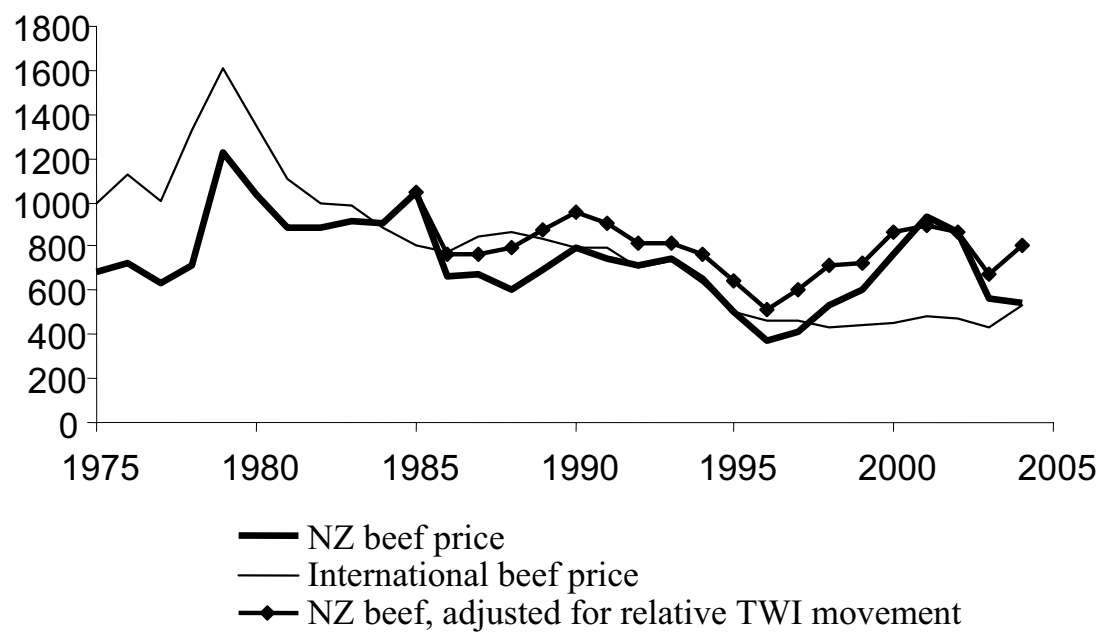


Figure 6 Inflation adjusted NZ (\$/kg MS) and international dairy price (c/lb), and N Z milksolids price adjusted for relative TWI movement (1990 base year)s.

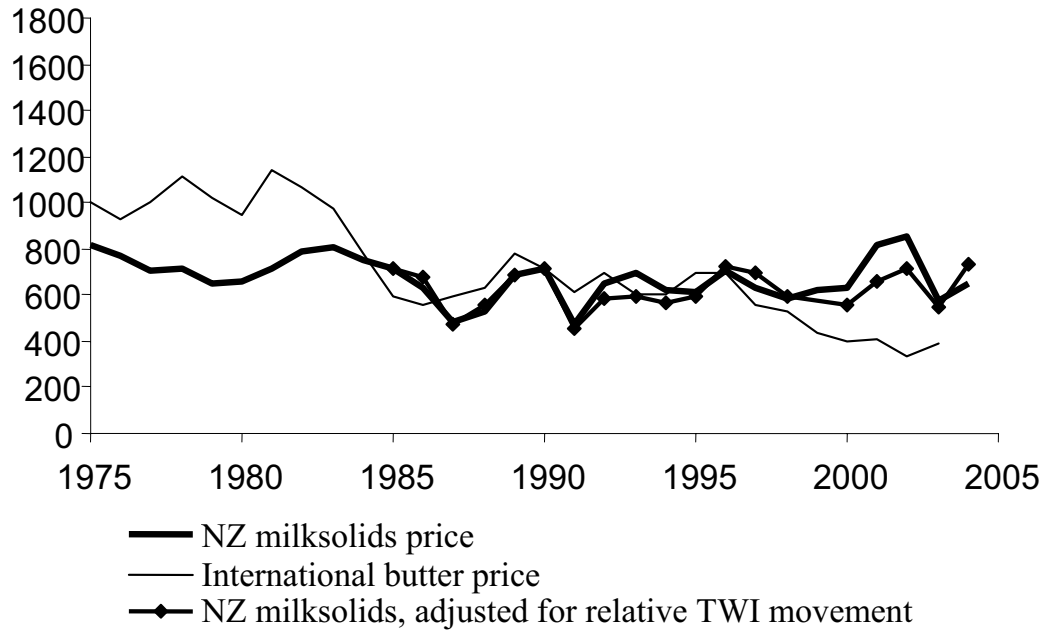

8 While the NZ milksolids price is determined by other final products than solely butter for this analysis the international butter price is assumed to be an accurate measure of international dairy prices as used by the IMF.

Source: Data adapted from IMF, LIC and RBNZ.

Figure 7 New Zealand exports by tonnage from 1985 to 2004 (1985 base year $=1000)$.

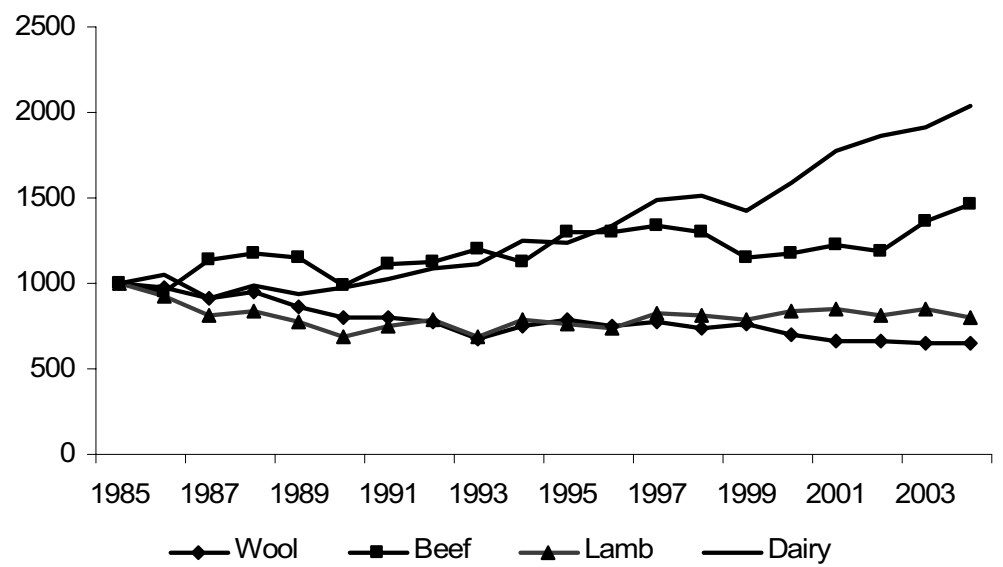

Source: MAF Policy (Note: dairy figures are in milkfat).

question for NZ dairy farmers is whether the current level of investment in value added products will be sufficient to sustain or even improve on this trend, given that the efficiencies achieved through dairy company mergers are probably now in the past. An additional question for the dairy, beef, and lamb industries is how much of the price increases/resilience have been driven by processing efficiencies, how much have been the result of improved marketing, and how much due to unique one-off gains resulting from disease outbreaks in competing agricultural countries?

\section{Production and productivity}

The balance of production has changed since 1985 toward dairying and beef (Figure 7). The increase in beef production could partially be as a result of the expansion of dairying.

In addition to the reversal of the long-term downward trend in real price for lamb, dairy, and beef, on-farm production has shown significant productivity gains, despite reductions in pastoral land area $^{4}$. Productivity increases are most notable in the sheep industry where lambing has increased $26 \%$, lamb

${ }^{4}$ Pastoral land area has decreased 15\% decrease in the twelve years following 1990/91 (Davison 2004). It was estimated that 34000 ha of farm land was lost to lifestyle blocks in 2004. 
Figure 8 Sheep numbers and total lamb weight killed 1975-2004.

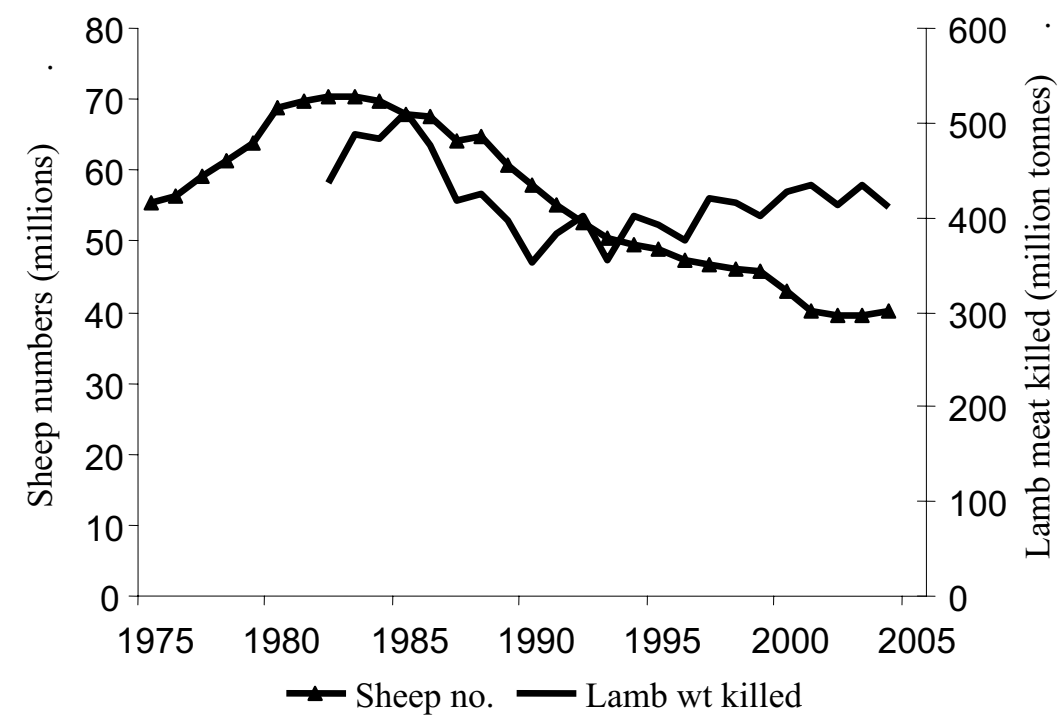

Source: Data adapted from MAF Policy, and MWNZES.

Figure 9 Dairy production $1975-2004$.

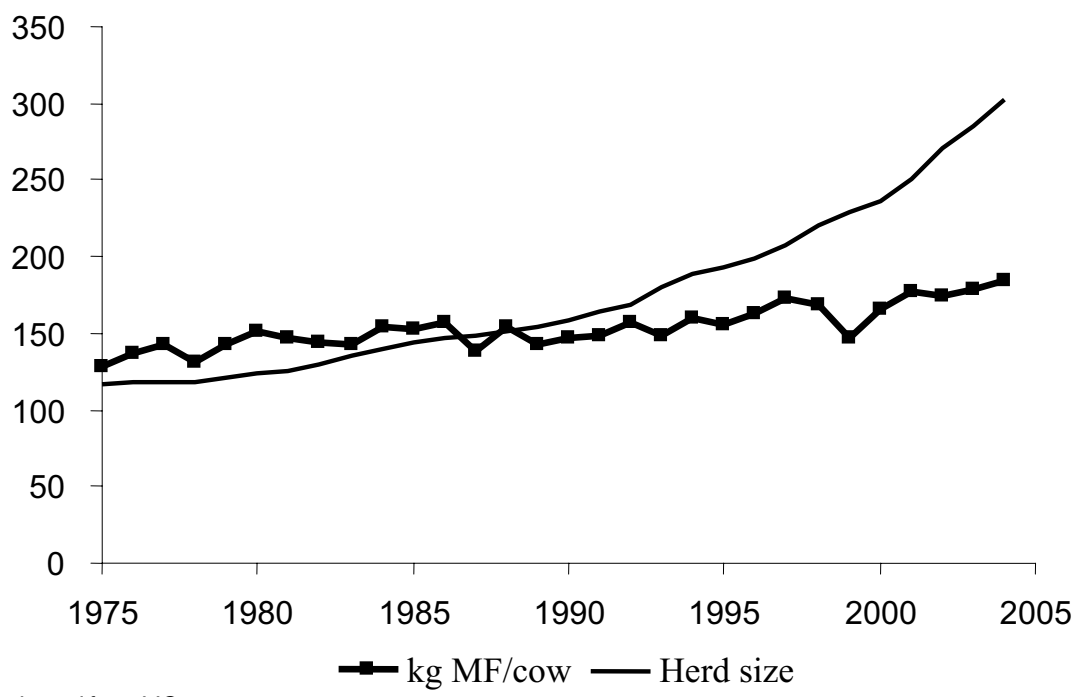

Source: Data adapted from LIC.

carcass weights have increased $20 \%$, and wool/hd has increased $10 \%$ since 1990. These increases have resulted in total lamb production increasing $10 \%$, despite a $32 \%$ decrease in the national sheep flock since 1990 (Figure 8).

Milkfat/cow has increased $44 \%$ at the same time as the average herd size has increased $158 \%$ since 1975 (Figure 9). It is worth noting that over the period that the dairy price has remained relatively constant (1985 onwards) while the volume of dairy exports has increased by $275 \%$. Obviously this is a reflection of the improvements made in marketing, processing, innovation, and production efficiencies on the farm.

\section{Profitability}

Measured in real terms, GFI, FWE, and EBIT for sheep farming fell steadily until the end of the 1990s, after which the impact of the productivity gains and price increases discussed earlier resulted in a 79\% increase in EBIT compared with the previous 5 years. Sheep farming, in real terms, is now close to the profitability levels of the late-1970s/early-1980s (Table 3, Figure 
Table 3 Profitability of 200 ha Southland sheep and dairy farms from the period 1970-1974 to 2000-2004 (real terms base year 1975).

\begin{tabular}{lccccccc}
\hline & $70-74$ & $75-79$ & $80-84$ & $85-89$ & $90-94$ & $95-99$ & $00-04$ \\
\hline Sheep & & & & & & & \\
GFI (\$) & 37982 & 36591 & 36546 & 26972 & 23513 & 22169 & 32894 \\
FWE (\$) & 17783 & 16689 & 18181 & 13151 & 11266 & 12409 & 16177 \\
Depn. (\$) & 2862 & 3161 & 2970 & 1676 & 1405 & 1636 & 2168 \\
EBIT (\$) & 17336 & 16740 & 15396 & 12145 & 10843 & 8124 & 14549 \\
EBIT change & & $-3 \%$ & $-8 \%$ & $-21 \%$ & $-11 \%$ & $-25 \%$ & $79 \%$ \\
Dairy & $70-74$ & $75-79$ & $80-84$ & $85-89$ & $90-94$ & $95-99$ & $00-04$ \\
GFI (\$) & & & & 62217 & 80564 & 88708 & 117750 \\
FWE (\$) & & & & 29251 & 44342 & 52125 & 63797 \\
Depn. (\$) & & & & 3816 & 4793 & 6700 & 6994 \\
EBIT (\$) & & & & 25667 & 31429 & 29883 & 46959 \\
EBIT change & & & & $22 \%$ & $-5 \%$ & $57 \%$ \\
\hline
\end{tabular}

Source: Data adapted from MWNZES survey of sheep and beef farms (Class 7 Southland intensive finishing) and Dexcel survey of dairy farms.

Figure 10 Profitability of a 200 ha Southland sheep and dairy farms from the period 1970-1974 to 2000-2004 (real terms base year 1975).

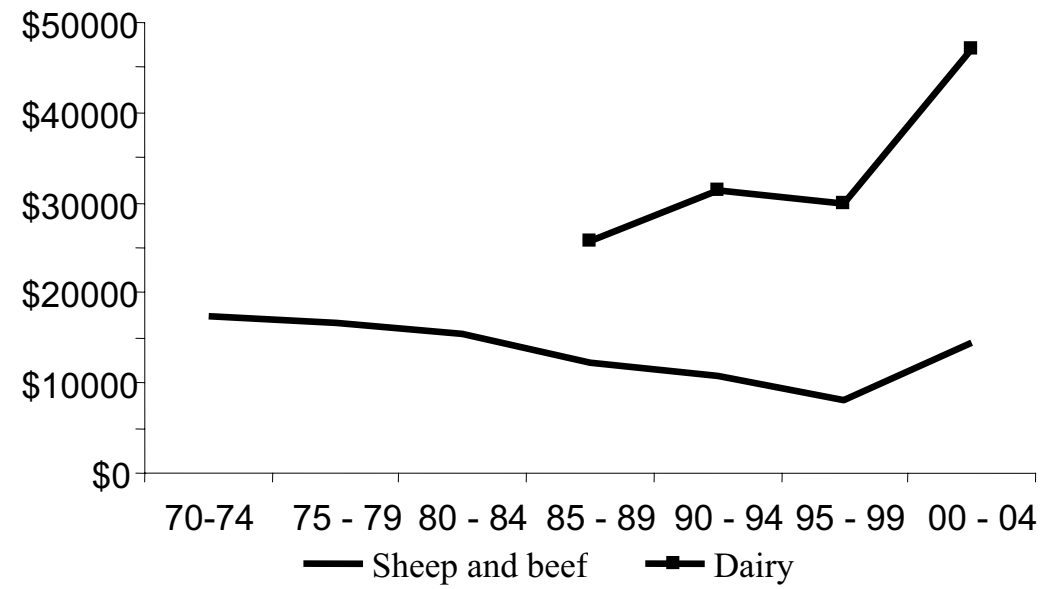

Source: Data adapted from MWNZES survey of sheep and beef farms (class 7 Southland intensive finishing) and Dexcel survey of dairy farms.

10). By comparison, dairying has held more constant, but still experienced a significant upward shift in EBIT in the past half decade (Table 3, Figure 10). As is well known, this has been a major driver in the significant increase in rural land prices.

It is interesting to note that sheep farmers run a lower cost structure in terms of expenses as a percentage of GFI. This probably reflects the difference in scale and profitability of dairying vs. sheep and beef and also the relative balance of marginal return versus marginal cost between the two sectors.

\section{Conclusions}

The excellent performance achieved in the NZ agricultural sector has been the result of cumulative improvements in production, processing, and marketing. At the farm level, per head animal performance, change in land use to higher value activities, more transparent market signals, improved farmer competence, increased land productivity, and the cumulative results of research and development and subsequent technology transfer have substantially increased farm level performance and profitability.

At the processing level, investment in processing rationalisation and technology, added value processing, product development, and marketing have resulted in improved efficiencies and better product prices. Lamb, dairy, and beef prices have flown in the face of international trends with lamb prices increasing and dairy and beef prices decreasing comparatively less than the international price. The unknown question is whether these trends are sustainable or whether they will revert to following the other long-term trends.

The cumulative performance increases at the farm 
and processing level have resulted in agriculture's contribution to GDP increasing $80 \%$ in the eleven years ending 2002 , or $5.4 \% / \mathrm{yr}$, in comparison to $37 \%$ growth in the rest of the economy, or $2.9 \% / \mathrm{yr}$ (Davison 2004). At the farm level, real profitability has increased on sheep and beef and dairy farms in the five years ending 2004. The challenge is to continue and improve upon this trend and cement NZ agriculture's place as the world leader in added value pastoral based agriculture.

\section{ACKNOWLEDGEMENTS}

Many thanks go to: Louise Abolins and Graham Howard, RBNZ; Joshua Adams, MWNZ; Murray Doak, MAF; Chris Glassey, Dexcel; Mat Moyes, Deer Industry New Zealand; and Jeremy Neild, Agriculture New Zealand, for assisting with source data. Also thanks to the two referees for valuable comments and suggestions.

\section{REFERENCES}

Brash, D. 1992. The exchange rate and monetary policy. Reserve Bank Bulletin 55/4: 324-333.

Brown, C. 1996. Financial viability - a long term view. Proceedings of the New Zealand Grassland Association 58: 7-12.

Davison, R. 1995. Farm Sector Exchange Rates, Production, Financial Trends, and Aggregate Output Paper No. G2079. Meat and Wool Boards Economic Service. Wellington.

Davison, R. 2004. Smoking performance from the pastoral sector. The New Zealand Meat Producer 32: 1 .

Meat and Wool New Zealand Economic Service. Economic Survey of New Zealand Sheep and Beef Farms. Meat and Wool New Zealand, Wellington.

West, A. 2005. Helping Crea te the Dairy Industry of the Future. Presentation to the Westpac Dairy Conference. Hawera. 